\title{
ENHANCING FARMER'S WELL BEING THROUGH THE AGRICULTURE LAND PROVISIONS IN WEST NUSA TENGGARA
}

\author{
Baiq Rindang Aprildahani ${ }^{1}$, Surya Tri Esthi Wira Hutama ${ }^{2}$, Chrisna Trie Hadi Permana ${ }^{3}$ \\ Urban and Regional Planning, Institut Teknologi Sumatera \\ E-mail: rindang.aprildahani@pwk.itera.ac.id
}

\begin{abstract}
While carrying out its essential duties to provide adequate foods for people, the agriculture sector is facing sustainability issues. The study presents a case study of West Nusa Tenggara (NTB), whereby an increase of urban expansion activities has begun to create a centrifugal force to the province that is popularly called as the granary of Indonesia. Urban settlements slowly leapfrogged to the outskirts and reduced the size of prime agricultural lands. Moreover, existing planning policies were unable to control the situation and many farmers leave their jobs because the setback of farmers wellbeing. The size of agricultural land is highly influential towards farmer motivation to stay engaged in the farming sector. Applying qualitative methods, this study examined the minimum area of agriculture land (focusing on paddy field) to promote farmer's well-being following three steps of the analytical framework: total agricultural production estimation, the average well-being estimation, and the prediction of minimum land provision for the average well-being. After all, one of the key important findings reveals that the average of minimum agricultural land to ensure famers wellbeing for the whole NTB Province is $0.74 \mathrm{Ha}$.
\end{abstract}

Keywords: Farmer's Well-Being; Agriculture Land; Paddy Fields.

\section{A. INTRODUCTION}

Landless and subsistence farmers have been long considered as the key issue in the developing and underdeveloped world. Their existence has continuously contributed to the poverty, inequality, and long-term unsustainability of farming activities. Unlike the majority of developed countries and their sufficient conditions of land and revenue of farmers, those living in the Global South, representing the majority of developing and underdeveloped countries, are at the stake of being risked by farming economy degradation whilst the actual demands of agricultural commodities increasing rapidly. Many issues are mostly related to poor knowledge and technology, structural transformation, land conversion and disconnected subsistence farmers against the backdrops of industrialization and globalization (European Parliament Research, 2018; Milton, 2003).

Whilst the challenges remain unsolved, various problems surrounding farmers are increasing, including current issues related to the failure of subsistence farmers to develop networking and innovation capacities, the unsuitability of national and local economic policies, as well as open-competition from modern farming and processing industries from developed countries (Arvianti et al., 2019). This situation is worsened by urbanization and peri-urban housing expansions (Parnell \& Oldfield, 2014). Many farmers are, thus, continuously losing their lands and struggle to fulfill 
basic needs to ensure their family wellbeing (Ayambirea et al., 2019; FAO, 2015).

Although the issues of urban expansion or sprawling have been going for more than two decades, planning approaches to provide effective solutions for sustainable peri-urban development remain challenging that makes the agricultural sector is continuously under scrutiny. Many scholars consider the existing policies are immature and yet to produce positive impacts that ensure the balance between urban and rural as well as agricultural and industrial sectors in many urban areas around the world (Parnell \& Oldfield, 2014). This situation is even more difficult in the emerging world, including Indonesia. This is in line with the problem of poverty in West Nusa Tenggara which is predominantly located in rural areas. NTB is one of provinces being considered as the granary of Indonesia. The total production of paddy in NTB is recognized as one of the largest in Indonesia (Indonesia Centre of Statistics Bureau, 2020). NTB Province that consists of ten districts has harvested paddy field at 281,666 $\mathrm{km}^{2}$ in 2019 . However, the size of paddy field has been declined at around $7,576.55 \mathrm{~km}^{2}$ from 2018 to 2019 (NTB Province Statistics Bureau, 2020a). It seems the urban expansion or sprawling in West Nusa Tenggara is going faster than the innovation of policy makers and planners. The growth of urban centres continuously creates a centrifugal force, resulting in a leapfrog development towards the outskirts, which usually causes the loss of prime agricultural lands and worsening the current setback of farmers' well-being.
The first stage of solving the problem around farmers in the developing and underdeveloped countries is to understand their average revenue and the overall wellbeing. In this paper, we aim at examining such figures to develop a general understanding to guide planners and policy makers to improve farmers' conditions and capacity based upon their minimum requirement of land, revenues, to reach the agreed wellbeing levels. The figures can be link towards certain strategies that can be undertaken to help farmers to reach their wellbeing levels. According to various literature, for instance, three aspects are defined as potential strategies, including technology and knowledge advancement (Markussen et al., 2018), technical innovations and methods, including intensification, cropping, as well as distribution and management (Sunderlin et al., 2001; Väth et al., 2019), and the traditional elements such as climate, land availability, and surrounding natures (Nipers et al., 2015).

In this paper, we applied a qualitative method, focusing on calculating and presenting data and information related to farmers' minimum land and revenue, which were discussed and compared together based upon the literature review. We firstly identified the total production value of agricultural sector. Secondly, we compare the value with regards to the minimum requirement of proper daily life, which later on, we considered as farmers' wellbeing. Finally, the actual minimum area of agriculture land per capita should be achieved by farmers to ensure their proper daily life. In this regard, we discussed why such figures were emerged, by looking at the actual conditions of farmers' land, climate, soil 
quality, agricultural methods and tools, as well as land actual locations. This topic is important in a way that the availability of land is the most essential factor determining the income of the farmers, in addition to the quality of lands, agricultural methods, tools, and the location of farmlands (Swinnen \& Knops, 2013).

\section{B. MATERIALS AND METHODS}

A qualitative method was applied through a case study approach. Our paper presents a case study of West Nusa Tenggara (NTB) Province in Indonesia as a research window through which the farmer's well-being was examined. NTB is one of provinces being considered as the granary of Indonesia. NTB Province that consists of ten districts has a very extensive land at approximately $2,012,448.00 \mathrm{~km}^{2}$. The agricultural land itself appears in the forms of harvested paddy field is 281,666 km² in 2019 (NTB Province Statistics Bureau, 2020a). However, the size of paddy field has been declined at around $7,576.55 \mathrm{~km}^{2}$ from $289,242.6 \mathrm{~km}^{2}$ in 2018 . This situation will continue following the massive urban expansion activities in a number of districts that began to experience urbanization. Agricultural sector is, in fact, linked to the overall economic condition in NTB. For instance, in addition to its function to ensure food supply, the agricultural sector also remains as one of the largest sectors absorbing employment.

In the case study analysis, a threestages examination framework was used to measure farmers well-being. This analytical framework was a mixed of Väth, Gobien and Kirk (2019) and Nipers,
Pilvere and Krievina (2015) on the farmland's standard of area and Saxby et al. (2018) on the overall farmers' economic well-being. The three stages of analytical framework include: (1) the assessment on the total production value of agricultural sector; (2) the assessment on the overall wellbeing of people in the region as the baseline for well-being measurement; and (3) the examination on the minimum agriculture land converted from the minimum expected prodution and the average wellbeing. Data and information were based on secondary data publication issued by national and local statistics bureau, which include: Indonesia in Figure, 2020; NTB Province in Figure, 2020; Result of Cost Structure Paddy Cultivation Household Survey NTB Province, 2017; Price Statistics of Grain Producers in NTB, 2019; and Agriculture Potential in Indonesia 2013.

In the first and second stages, the assessment of the total production value of agricultural sector and its overall farmer's wellbeing, our analysis provides an illustration about how much farmers in particular area could earn from their average production activities within a specific normal period. This indicator provides information about the production capacity with regards to farmers products, skill specialisations, and area capacity (Latruffe \& Piet, 2014). Total production value also indicates farmers prospect with regards to their financial management capacities such as production costs, yields, revenue, profitability, technical and scale efficiency (Väth et al., 2019). The size of farmland necessary for earning is especially matter when the farmer possesses ownership or shares (The Business Line, 2018). In this regard, we 
calculate the average agriculture area, production number, and average productivity level to describe total production value. The total production is then used to estimate the minimum revenue could be earned to define the overall farmer's wellbeing.

In the final stage, the examination on the minimum agriculture land required for farmers wellbeing, we provides the final assessment to draw the conclusion. It is converted from the minimum expected prodution and its value, which is compared to the average wellbeing in the region. Various studies indicate the average minimum agriculture area necessary for farmers to achieve their wellbeing is contextual. In Eastern Europe, for instance, for grazing livestock farming, the total area required to ensure minimum income for farmer wellbeing is 53.7 ha, as for field crop farming, the total area required is 65 ha (Nipers et al., 2015). This condition is based on the average of land owned/rented by the farmers in European countries, including more than 50 ha in more developed countries such as Denmark, Luxembourg, France, and the United Kingdom; and less than 5 ha in more developing countries such as Malta, Romania, Cyprus, and Greece (Nipers et al., 2015).

In providing our justification about farmer's wellbeing, we focus on the comparison of farmer's average wellbeing in many countries in the Global South. Our literature review emphasizes that the average of land owned/rented by farmers is significantly lower than those in the Global North. It is only around 1 ha, whilst in other cases in the Global North could reach 4-5 ha. In India, for instance, many farmers only have an average 0.8 ha land area, this situation applies for both crop and livestock farming (Pochanasomboon et al., 2020). In Thailand, despite the average of land owned by farmer, measured by the proportion of farming land per farmer household by the FAO, the average can reach 4 ha, but the actual facts have shown that many farmers are actually possessing only less than 1 ha (Susilowati \& Maulana, 2012). Worse than that, farmer household according to land area ownership classification in Indonesia 2013, the average of farmer owns less than 0.5 ha (Indonesia Centre of Statistics Bureau, 2014). This comprises of around $16 \%$ farmers with less than 0.1 ha, $40 \%$ farmers with land ownerships between 0.1-0.5. This situation especially occurs in crop farming (European Parliament Research, 2018; Saxby et al., 2018). We use this theoretical underpinning as the general hypothesis.

\section{RESULTS AND DISCUSSION}

\section{The Total Production Value of Agriculture Sector}

The total production of paddy in NTB is recognized as one of the largest in Indonesia (Indonesia Centre of Statistics Bureau, 2020). The following Table 1 shows the actual report of land area, production, and productivity level of paddy per district in NTB from 2018 to 2019. The level of productivity is one factor that determines the minimum of land requirement for farmer wellbeing. Table 1 indicates that the average productivity of paddy in NTB Province has reached $66.86 \mathrm{Ku} / \mathrm{Ha}$. It is to highlight that Mataram City appeared as the most productive area, whilst West Sumbawa Regency stood 
as the least productive area. By looking at this productivity level, it can be understood that the farmers in the
Mataram City requires less agricultural land to ensure their wellbeing.

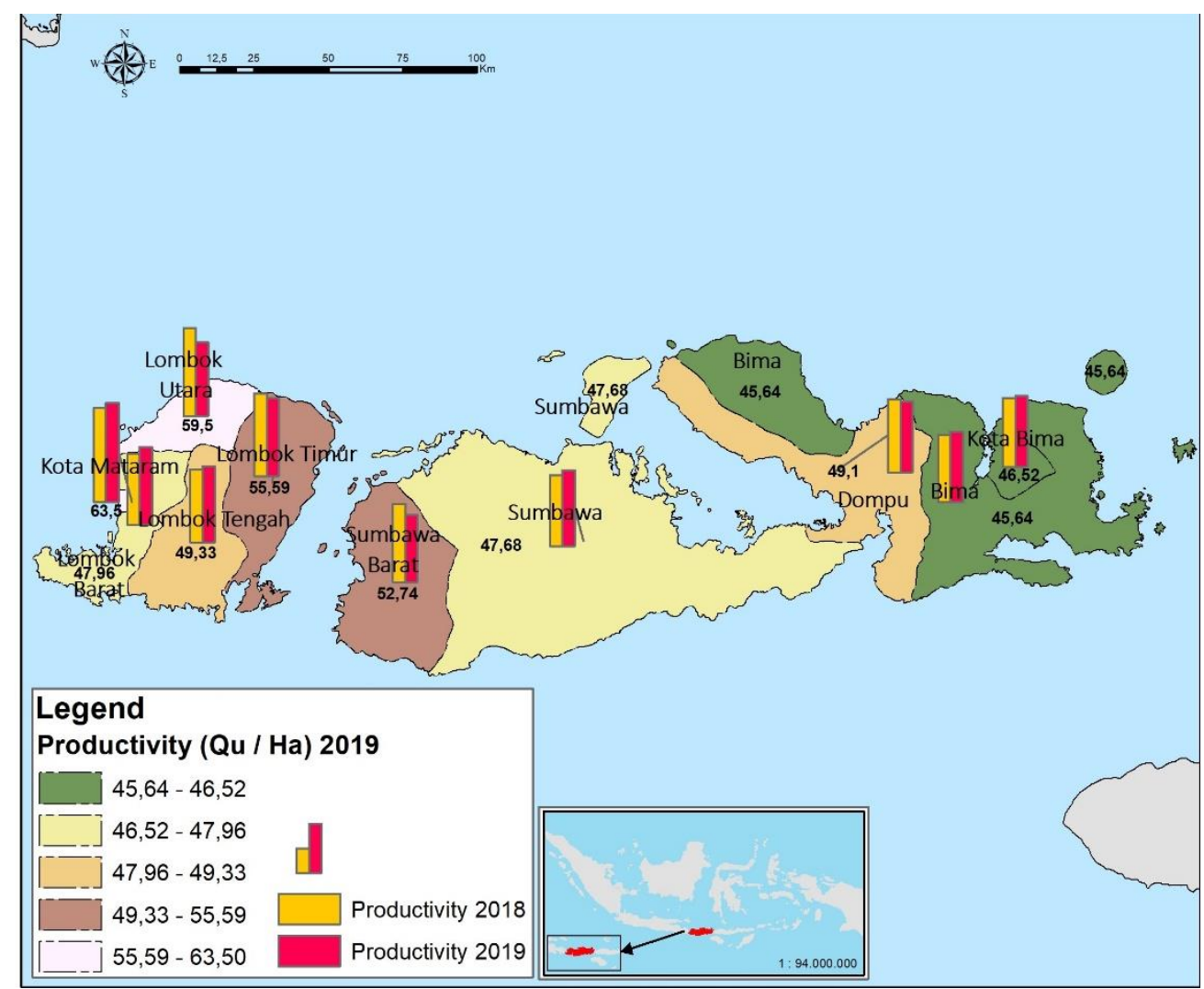

Figure 1. Distribution of Paddy Productivity in NTB Province (Qu/Ha) Source: (NTB Province Statistics Bureau, 2020a)

Table 1. Harvested Area, Production, Productivity of Paddy by District in NTB, 2018 \& 2019

\begin{tabular}{lllllll}
\hline \multicolumn{1}{c}{$\begin{array}{l}\text { Regency } \\
\text { /Municipality }\end{array}$} & \multicolumn{2}{c}{ Harvested area (ha) } & \multicolumn{2}{c}{$\begin{array}{c}\text { Productivity } \\
\text { (qu/ha) }\end{array}$} & \multicolumn{2}{c}{ Production (ton) } \\
& 2018 & 2019 & 2018 & 2019 & 2018 & 2019 \\
\hline $\begin{array}{l}\text { Lombok Barat } \\
\text { Lombok }\end{array}$ & 22249.51 & 24270.51 & 52.2 & 47.96 & 116147.72 & 116409.68 \\
$\begin{array}{l}\text { Tengah } \\
\text { Lombok }\end{array}$ & 74447.59 & 71942.57 & 51.24 & 49.33 & 381436.4 & 354915.09 \\
Timur & 48146.39 & 46834.06 & 52.63 & 55.59 & 253392.2 & 260367.37 \\
Sumbawa & 56302.94 & 58110.22 & 50.91 & 47.68 & 286642 & 277059.24 \\
$\begin{array}{l}\text { Dompu } \\
\text { Bima }\end{array}$ & 21165.96 & 18824.53 & 47.62 & 49.1 & 100787.3 & 92429.31 \\
$\begin{array}{l}\text { Sumbawa } \\
\text { Barat }\end{array}$ & 43300.52 & 39868.54 & 47.66 & 45.64 & 206371.9 & 181943.26 \\
$\begin{array}{l}\text { Lombok } \\
\text { Utara }\end{array}$ & 58474.35 & 11999.96 & 45.21 & 52.74 & 56400.51 & 63282.3 \\
Kota Mataram & 2426.49 & 2465.79 & 66.86 & 63.5 & 16224.24 & 15658.14
\end{tabular}




\begin{tabular}{clllllc}
$\begin{array}{c}\text { Regency } \\
\text { /Municipality }\end{array}$ & \multicolumn{2}{c}{ Harvested area (ha) } & \multicolumn{2}{c}{ Productivity } & \multicolumn{2}{c}{ Production (ton) } \\
& 2018 & 2019 & 2018 & 2019 & 2018 & 2019 \\
\hline Kota Bima & 2886.09 & 2783.17 & 47.8 & 46.52 & 13794.15 & 12947.59 \\
\hline
\end{tabular}

Source: (NTB Province Statistics Bureau, 2020a)

For farmers, the value of paddy production is far from expectation. The following Table 2 indicates the detailed total production and cost of production in NTB Province using data of year 2017. Production cost is a total cost provided by farmer family for every 1 hectare of paddy per season. This total amount can only cover a minimum quality of farming production, already include the estimation of land rent, land tax, production tools rent, workers fee and the overall credit interest is calculated by imputation approach. Data included in the Table 2 was obtained from the Result of Cost Structure Paddy
Cultivation Household Survey, 2017. The total of production cost of wetland paddy per season per hectare is $79 \%$ and the cost of dryland paddy is $94 \%$ from the total of production. The production cost component of paddy that appears as the largest in proportion is service fee and worker fee. Meanwhile, the actual revenue gained from the production activity per hectare per season for wetland paddy $(21 \%)$ and dryland paddy $(8 \%)$ from the total of production. On average, the final revenue is $13 \%$ whilst the cost of production itself is $87 \%$.

Table 2. Production Value and Production Cost Per Planting Season Per Hectare of Paddy Cultivation in NTB Province, 2017

\begin{tabular}{lrrrr}
\hline \multirow{2}{*}{ Descriptions } & \multicolumn{2}{c}{ Wetland paddy } & \multicolumn{2}{c}{ Dryland paddy } \\
\cline { 2 - 5 } & $\begin{array}{c}\text { Value } \\
\text { (thousand } \\
\text { rupiahs) }\end{array}$ & $\%$ & $\begin{array}{c}\text { Value } \\
\text { (thousand } \\
\text { rupiahs) }\end{array}$ & $\%$ \\
\hline A. Production & $18,393.06$ & 100 & $8,821.62$ & 100 \\
\hline 1. Main production & $18,354.66$ & 99.791225 & $8,797.8$ & 99.7308884 \\
\hline 2. Secondary production & 38.38 & 0.2086656 & 23.74 & 0.26911156 \\
\hline B. Production cost & $14,562.03$ & 79.171328 & $8,290.3$ & 93.9772966 \\
\hline 1. Seeds & 778.14 & 4.2306174 & 456.43 & 5.17399298 \\
\hline 2. Fertilizers & $1,043.81$ & 5.6750209 & 633.1 & 7.17668636 \\
\hline 3. Pesticides & 543.88 & 2.9569848 & 485.85 & 5.50749182 \\
\hline 4. Wages and agricultural & $7,420.20$ & 40.342390 & $4,576.4$ & 51.8773195 \\
\hline services & $2,624.11$ & 14.266848 & $1,810.1$ & 20.5194737 \\
\hline A. Paid workers & $1,972.62$ & 10.724805 & $2,050.8$ & 23.2482242 \\
\hline B. Unpaid workers & $2,823.47$ & 15.350735 & 715.4 & 8.10962158 \\
\hline C. Agricultural services & $3,236.21$ & 17.594734 & $1,206.4$ & 13.6760595 \\
\hline 5. Estimation of land rent & 66.86 & 0.3635066 & 34.54 & 0.39153806 \\
\hline 6. Tax/Estimation of Tax & & & & 193
\end{tabular}




\begin{tabular}{|c|c|c|c|c|}
\hline \multirow[b]{2}{*}{ Descriptions } & \multicolumn{2}{|c|}{ Wetland paddy } & \multicolumn{2}{|c|}{ Dryland paddy } \\
\hline & $\begin{array}{c}\text { Value } \\
\text { (thousand } \\
\text { rupiahs) }\end{array}$ & $\%$ & $\begin{array}{l}\text { Value } \\
\text { (thousand } \\
\text { rupiahs) }\end{array}$ & $\%$ \\
\hline $\begin{array}{l}\text { 7. Loan Interests/Estimation of } \\
\text { loan Interests }\end{array}$ & 79.06 & 0.4298360 & 86.28 & 0.97805165 \\
\hline 8. Levies/charges/dues & 102.75 & 0.5586346 & 8.56 & 0.09703433 \\
\hline 9. Insurance & 0 & 0 & 0 & 0 \\
\hline $\begin{array}{l}\text { 10. Tools Rent/Estimation of } \\
\text { tools rent }\end{array}$ & 509.44 & 2.7697403 & 253.83 & 2.87736266 \\
\hline 11. Shrinkage & 368.55 & 2.0037448 & 315.37 & 3.57496695 \\
\hline 12. Fuels & 146.57 & 0.7968766 & 84.68 & 0.95991439 \\
\hline I. Oil fuels & 146.57 & 0.7968766 & 84.68 & 0.95991439 \\
\hline Ii. Elpiji/gas fuels & 0 & 0 & 0 & 0 \\
\hline 13. Others & 266.56 & 1.4492422 & 148.81 & 1.68687837 \\
\hline C. Revenues & $3,831.03$ & 20.828671 & 531.30 & 6.02270331 \\
\hline \multicolumn{5}{|l|}{ E. Supporting information } \\
\hline 1. Costs per $\mathrm{kg}$ & \multicolumn{2}{|c|}{2.98} & \multicolumn{2}{|c|}{3.42} \\
\hline 2. Producer Prices per kg & \multicolumn{2}{|c|}{3.75} & \multicolumn{2}{|c|}{3.63} \\
\hline 3. Produktivity (qu/ha) & \multicolumn{2}{|c|}{48.94} & \multicolumn{2}{|c|}{24.22} \\
\hline $\begin{array}{l}\text { 4. Profit of Farmers per } \\
\text { month per ha }\end{array}$ & \multicolumn{2}{|c|}{957.76} & \multicolumn{2}{|c|}{132.82} \\
\hline
\end{tabular}

Source: (NTB Province Statistics Bureau, 2017)

Total production is a calculation of production based on the money value measurement obtained from the revenue of farmer family per hectare commodity per season. This amount includes the main production value in the basic quality and its following production value. According to Table $\mathbf{2}$, it is informed that the actual income of farmer per month per hectare for wetland paddy is Rp. 957,760 whilst for dryland paddy is Rp. 132,820 , the two values are below the minimum income of districts in NTB Provinces (see Table 3). Although paddy can be produced every year, production activities are highly depending on the availability water. Three periods of harvesting are (1) the main season November to March, (2) the transition season April to July, and (3) the dry season between August and October (Sumarno, 2006). This means the actual farmers can do effective production is only four months per year.

\section{The Assessment on the Overall Wellbeing in the Region}

As explained earlier, this study expects to provide analysis of the minimum required land for farmers to fulfill their wellbeing. It is therefore, the calculation of wellbeing is crucial. Farmer's wellbeing is associated with a dynamic process of people in maintaining their lives and development. It is multidimensional, allowing indicators such as the level of income, asset and wealth, social status and power, as well as knowledge and creativity, as key determinants of 
farmers wellbeing (Kumar et al., 2020). The key indicators are varied, depending on the overall country's living standard. Looking at the case of India, for instance, the level of farmer wellbeing is determined by their daily income and access to credit to formal financial institution ( $\mathrm{Lu} \&$ Horlu, 2017). In Ghana, the farmer wellbeing is closely associated with farm size holding and farmer business networking (Ma et al., 2020). In China, in a slightly different perspective, much research emphasis the access to technology advancement (including ICT) and knowledge improvement as one of the most crucial factor for farmers wellbeing (Kosanlawit et al., 2017; Sunderlin et al., 2001). Meanwhile in the Southeast Asia, like Thailand and Indonesia, the farmer level of wellbeing is still influenced by the crops land availability, agricultural market stability, and access to basic infrastructure (Rusdiana, 2014). The identification results show that the income from the agricultural business has a significant effect on the productivity of the farmer's workforce (Rusdiana, 2014).

Based on the available data and information, we use secondary data published by the government from survey result. In the calculation process, the formula is decided through the comparison of minimum provision of basic daily life, which is regard to the productivity and economic growth (Menteri Tenaga Kerja dan Transmigrasi Indonesia, 2012). On its mechanism, the minimum wage is set based on the recommendation of Income Agency of the Province, which is agreed by the Governor. The agency is a representative of government, academics, labor representative, and businessmen, which are adjusted to the actual cost of living in each area and level of labor. In summary, the minimum wage of each district in NTB Province is varied. As an effort to equalize the calculations in this study, the minimum wage will be adjusted to the time of paddy season which is assumed to be four months. 


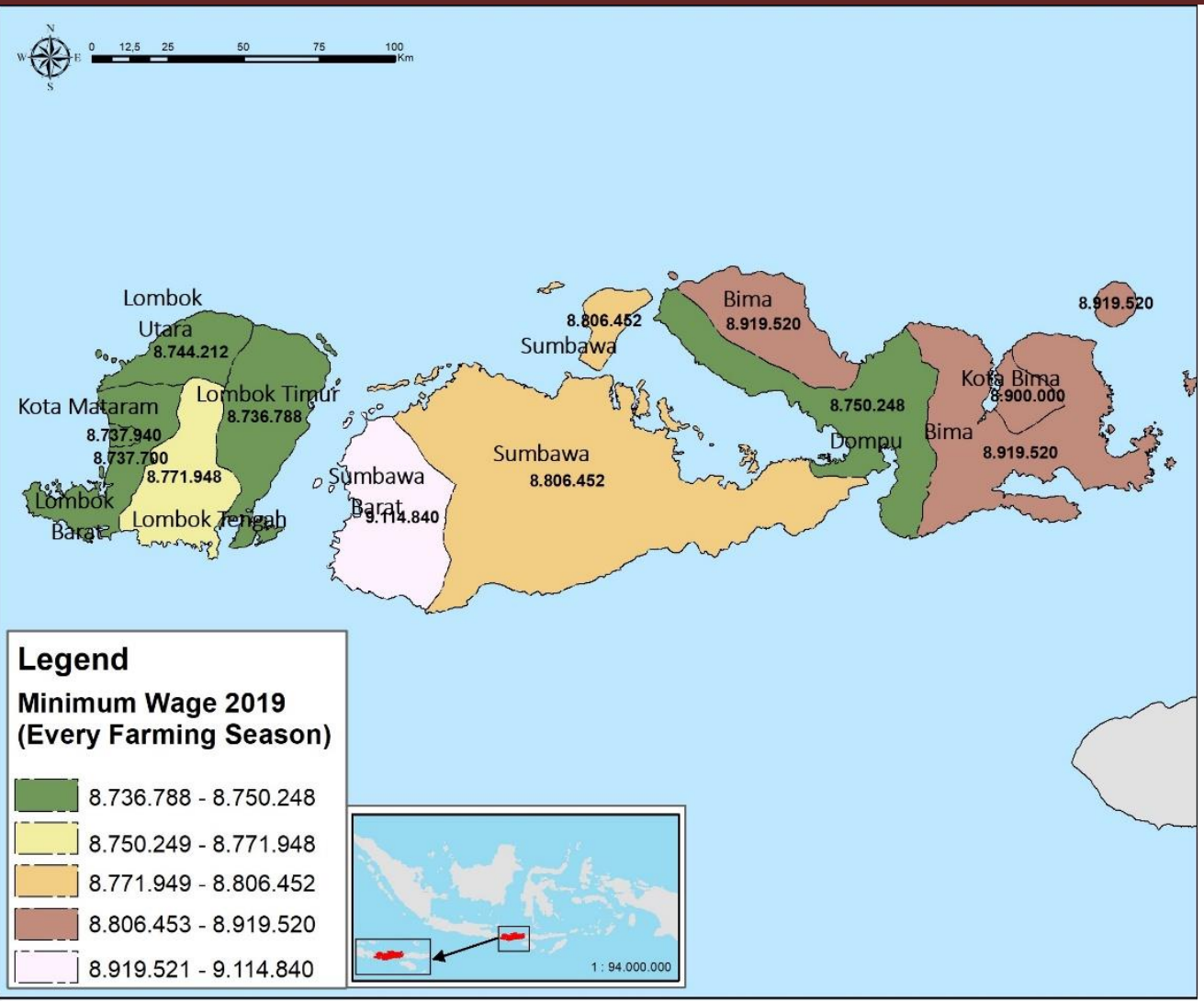

Figure 2. Distribution of District Minimum Wage / Paddy Season in NTB Province (Rupiah/Season)

Source: (Indonesia Centre of Statistics Bureau, 2020)

Table 3. The Requirement Production Value of Paddy Cultivation Per Paddy Season, 2019

\begin{tabular}{lcccc}
\hline $\begin{array}{c}\text { Regency } \\
\text { /Municipality }\end{array}$ & $\begin{array}{c}\text { Province } \\
\text { minimum } \\
\text { wage per } \\
\text { month } \\
\text { (rupiah) }\end{array}$ & $\begin{array}{c}\text { Province } \\
\text { minimum } \\
\text { wage per } \\
\text { paddy season } \\
\text { (rupiah) }\end{array}$ & $\begin{array}{c}\text { Production } \\
\text { cost of paddy } \\
\text { cultivation } \\
\text { per season } \\
\text { (rupiah) }\end{array}$ & $\begin{array}{c}\text { The requirement } \\
\text { production value } \\
\text { of paddy } \\
\text { cultivation per } \\
\text { season (rupiah) }\end{array}$ \\
\hline Lombok Barat & $2,184,425$ & $8,737,700$ & $7,601,799$ & $16,339,499$ \\
Lombok & $2,192,987$ & $8,771,948$ & $7,631,594.76$ & $16,403,543$ \\
Tengah & $2,184,197$ & $8,736,788$ & $7,601,005.56$ & $16,337,794$ \\
Lombok Timur & $2,201,613$ & $8,806,452$ & $7,661,613.24$ & $16,468,065$ \\
Sumbawa & $2,187,562$ & $8,750,248$ & $7,612,715.76$ & $16,362,964$ \\
Dompu & $2,229,880$ & $8,919,520$ & $7,759,982.4$ & $16,679,502$ \\
Bima & $2,278,710$ & $9,114,840$ & $7,929,910.8$ & $17,044,751$ \\
Sumbawa & $2,186,053$ & $8,744,212$ & $7,607,464.44$ & $16,351,676$ \\
Barat & $2,184,485$ & $8,737,940$ & $7,602,007.8$ & $16,339,948$ \\
Lombok Utara & $2,225,000$ & $8,900,000$ & $7,743,000$ & $16,643,000$ \\
Kota Mataram & Kota Bima & & &
\end{tabular}

Source: Analysis Result, 2020 
The expectation of minimum production of paddy per season is calculated based upon the sum of the average minimum income per season and the overall production cost of paddy per season in the same year (2019). The overall production cost itself was obtained from the stipulation of $87 \%$ of the total percentage of production cost as is shown in Table 2. The minimum production value of paddy is varied between districts, with West Sumbawa Regency remains the highest and East Lombok Regency as the lowest. East Lombok Regency became the lowest because its minimum income value was one of the lowest in the region. Furthermore, based on the expectation of minimum production value of paddy per season, it is understood that farmers in East Lombok Regency requires less farming area to ensure their wellbeing.

\section{The Assessment on the Requirement of Minimum Agriculture Land for Farmer's Wellbeing}

Policies related to agricultural sector in NTB Province is mostly based on the Indonesian National Policy. In the current periods, for instance, both spatial planning and agricultural development policies have not been fully integrated, causing many contradictionary decisions in both national and local levels of the spatial planning arrangement for urban infrastructure and agricultural lands (Setiawan, 2000). The Law No 41/2009 regarding the National Policy on Sustainable Agricultural Land that stipulates the intention to develop sustainable land farm continuously receives many challenges, even from the farmers themselves (Goverment of Indonesia, 2009). Many farmers decided to release their lands due to economic reasons, and hence, they become the actual actors who determine the conversion of agricultural land into urban functions. It is difficult for the government and planners to control farmer decision, whilst at the same time, both government and planners are unable to provide sufficient incentives for them.

Previous studies show that the ability of peri-urban agriculture to accommodate self-provision of food and to ensure adequate income for farmers appear as the most prominent motivation which encourage farmers to stay engaged in farming sectors (Adrianto et al., 2013). It is also important for policy makers and planners to involve farmers in various collaborative forums, allowing them to feel pampered, accommodated, and supported, so then they are willing to continue working in this sector. The availability of land is the most essential factor determining the income of the farmers, in addition to the quality of lands, agricultural methods, tools, and the location of farmlands (Swinnen \& Knops, 2013).

Based on the standard calculation, the next step is to convert the overall value of wellbeing into the area size. This analysis is required to understand the requirement of land area to fulfill farmer basic living condition. A number of additional factors determining farmers wellbeing are productivity and price of farming commodity. In the context of paddy, 
the price of commodity is calculated by the price of dry rice at the level of processing because this position has already included the main expenses, such as farmers production cost and processing cost. According to Price Statistics of Grain Producers in NTB 2019 , the average price of dry rice is Rp. Rp 4,361/Kg (NTB Province Statistics Bureau, 2020b).

After receiving the expectation of minimum production value of paddy per season (Rp), this indicator is divided by the average of the dry rice price $(\mathrm{Rp} / \mathrm{Kg})$ so then the expectation of minimum production of paddy per season $(\mathrm{Kg})$ can be obtained. That number then divided by the paddy productivity $(\mathrm{Kg} / \mathrm{Ha})$ to calculated the total minimum land area $(\mathrm{Ha})$ in the same year, 2019. The following Table

4 describes the detail calculation of each district in NTB Province. From the ten districts, Bima Regency indicates the largest agricultural land areas requirement to fulfill farmer welfare. The analysis result shows that farmer in Bima Regency requires at least $0.84 \mathrm{Ha}$ to be able to survive and support their wellbeing. This finding is determined by the level paddy productivity this district, which is the lowest in the region. Meanwhile, farmers need only $0.59 \mathrm{Ha}$ to ensure their wellbeing in Mataram City. This finding is determined by the highest level of paddy productivity and the level of minimum income, which is considered as one of the lowest in the region.

Table 4. Land Area Requirement of Paddy Fields for Farmer's Wellbeing, 2019

\begin{tabular}{lrcccc}
\hline \multicolumn{1}{c}{$\begin{array}{c}\text { Regency/ } \\
\text { Municipality }\end{array}$} & $\begin{array}{c}\text { Average grain } \\
\text { price in the } \\
\text { grinding } \\
\text { (Rupiah / Kg) }\end{array}$ & $\begin{array}{c}\text { Paddy } \\
\text { productivity } \\
\text { (Kg/Ha) }\end{array}$ & $\begin{array}{c}\text { The requirement } \\
\text { production value of } \\
\text { paddy cultivation } \\
\text { per season } \\
\text { (Rupiah) }\end{array}$ & $\begin{array}{c}\text { The requirement } \\
\text { production of } \\
\text { paddy cultivation } \\
\text { per season (kg) }\end{array}$ & $\begin{array}{c}\text { Land area } \\
\text { requirement } \\
\text { (ha) }\end{array}$ \\
\hline Lombok Barat & $4,361.36$ & 4796 & $16,339,499$ & 3746.422905 & 0.781155735 \\
Lombok Tengah & $4,361.36$ & 4933 & $16,403,543$ & 3761.10726 & 0.762438123 \\
Lombok Timur & $4,361.36$ & 5559 & $16,337,794$ & 3746.031871 & 0.673867939 \\
Sumbawa & $4,361.36$ & 4768 & $16,468,065$ & 3775.901379 & 0.791925625 \\
Dompu & $4,361.36$ & 4910 & $16,362,964$ & 3751.803052 & 0.764114675 \\
Bima & $4,361.36$ & 4564 & $16,679,502$ & 3824.381019 & 0.837945008 \\
Sumbawa Barat & $4,361.36$ & 5274 & $17,044,751$ & 3908.127465 & 0.741017722 \\
Lombok Utara & $4,361.36$ & 5950 & $16,351,676$ & 3749.215025 & 0.630120172 \\
Kota Mataram & $4,361.36$ & 6350 & $16,339,948$ & 3746.525808 & 0.590004064 \\
Kota Bima & $4,361.36$ & 4652 & $16,643,000$ & 3816.011519 & 0.820294824 \\
\hline
\end{tabular}

Source: Analysis Result, 2020 


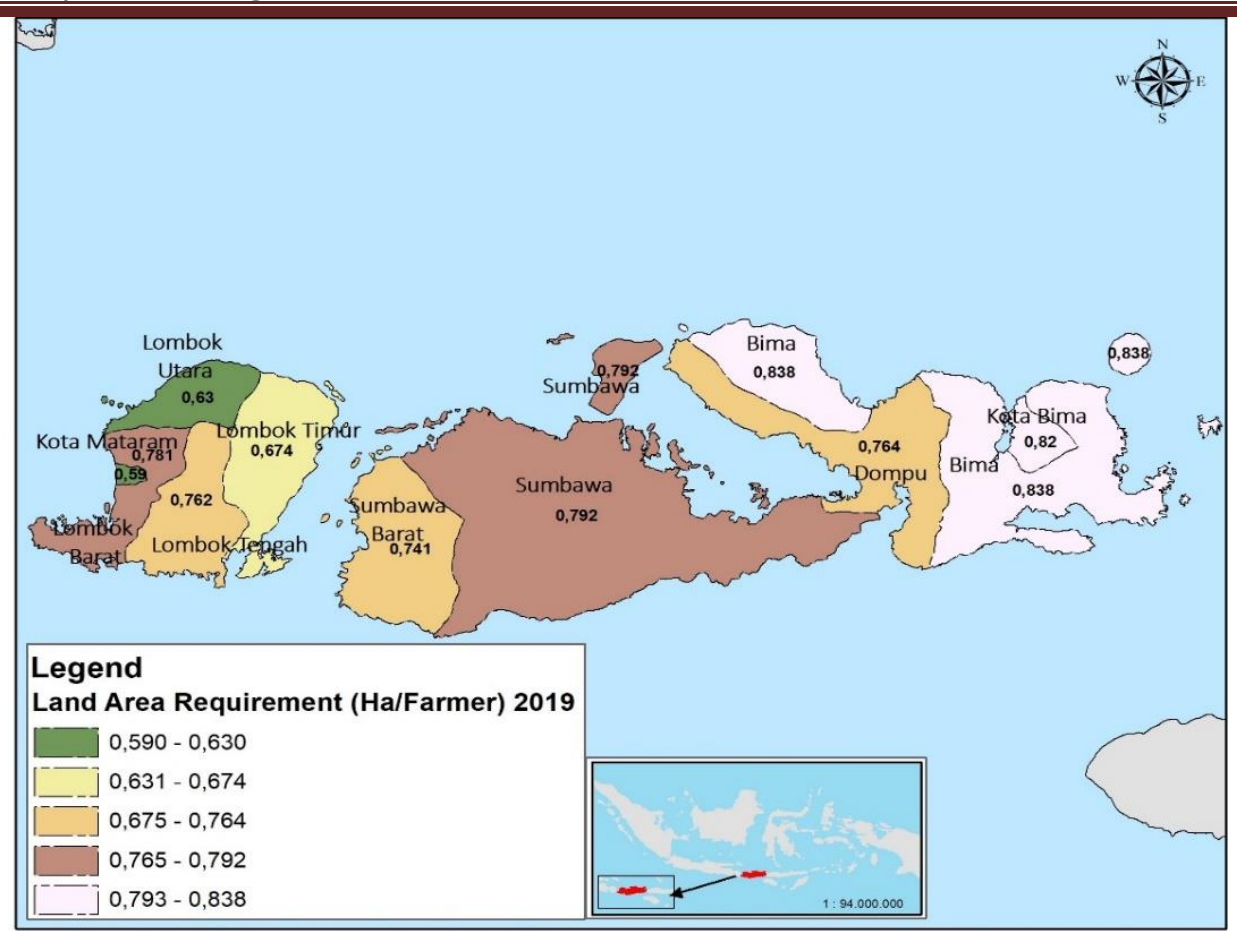

Figure 3. Distribution of Paddy Land Requirement for Farmer's Wellbeing (Ha/farmers) Source: Analysis Result, 2020

Finally, the average of minimum agricultural land to ensure famers wellbeing for the whole NTB Province is calculated to be $0.74 \mathrm{Ha}$ per capita. This area is far from the actual farmers land ownership average in Indonesia. Based on Table 5, it is recorded that the total farmers that have more than 0.5 Ha agricultural lands are only $44 \%$, whilst the rests are small farmers with less than 0.5 ha. Again, our identification has shown that the number of small farmers is continuously increasing because this category of farmers is not well supported by the government policy as well as incentives. Many of them converted their job due to economic difficulties.

Table 5. Farmer Household According to Land Area Ownership Classification in Indonesia, 2003 \& 2013

\begin{tabular}{|c|c|c|c|c|c|}
\hline \multirow{2}{*}{$\begin{array}{c}\text { Land area } \\
\text { qualification } \\
(\mathrm{Ha})\end{array}$} & \multicolumn{4}{|c|}{ Farmer household } & \multirow{2}{*}{$\begin{array}{c}\text { Growth } \\
\text { (\%) }\end{array}$} \\
\hline & 2003 & $\%$ & 2013 & $\%$ & \\
\hline$<0.1$ & $9,380,300$ & 30.03 & $4,338,894$ & 16.60 & -53.75 \\
\hline $0.1-0.1999$ & $3,602,348$ & 11.53 & $3,550,180$ & 13.58 & -1.45 \\
\hline $0.2-0.4999$ & $6,816,943$ & 21.83 & $6,733,362$ & 25.76 & -1.23 \\
\hline $0.5-0.9999$ & $4,782,812$ & 15.31 & $4,555,073$ & 17.43 & -4.76 \\
\hline $1-1.9999$ & $3,661,529$ & 11.72 & $3,725,849$ & 14.26 & 1.76 \\
\hline 2-2.9999 & $1,678,358$ & 5.37 & $1,623,428$ & 6.21 & -3.27 \\
\hline$\geq 3$ & $1,309,896$ & 4.19 & $1,608,728$ & 6.16 & 22.81 \\
\hline Jumlah & $31,232,184$ & 100.00 & $26,135,469$ & 100.00 & -16.32 \\
\hline
\end{tabular}

Source: (Indonesia Centre of Statistics Bureau, 2014) 


\section{CONCLUSIONS}

This study aims to investigate opportunities to preserve agriculture land. Applying qualitative research method, the study is able to identify the minimum area of agriculture land (especially paddy field) that support farmers' well-being. The average of minimum agricultural land to ensure famers wellbeing for the whole NTB Province is $0.74 \mathrm{Ha}$ per capita. This area is far from the actual farmers land ownership average in Indonesia. Farmer Household According to Land Area Ownership Classification in Indonesia (2003 and 2013) recorded that the total farmers that have more than $0.5 \mathrm{Ha}$ agricultural lands are only $44 \%$, whilst the rests are small farmers with less than 0.5 ha.

\section{E. REFERENCES}

Adrianto, D. W., Aprildahani, B. R., Subagiyo, A. (2013). Tackling the Sprawl, Protecting the Parcels: An Insight into the Community's Preference on Periurban Agricultural Preservation. Spaces and Flows: An International Journal of Urban and ExtraUrban Studies, 3, 115-125.

https://www.researchgate.net/profil e/Olon-

Dotson/publication/307765536_Phy sical_Places_and_Ideological_Spac es/links/5832ef3b08ae102f0736592 c/Physical-Places-and-IdeologicalSpaces.pdf\#page $=128$

Arvianti, E. Y., Masyhuri, M., Waluyati, L. R., \& Darwanto, D. H. (2019). Gambaran Krisis Petani Muda Indonesia. Agriekonomika, 8(2), 168-180.

https://doi.org/10.21107/agriekono mika.v8i2.5429

Ayambirea, R. A., Amponsaha, O.,
Pepraha, C., \& Takyi, S. A. (2019). A review of practices for sustaining urban and peri-urban agriculture: Implications for land use planning in rapidly urbanising Ghanaian cities. Land Use Policy, 84(2019), 260277.

https://doi.org/10.1016/j.landusepol. 2019.03.004

European Parliament Research. (2018). Small Farmers [What Europe Does For You]. https://epthinktank.eu/2018/05/19/s mall-farmers-what-europe-does-foryou/ (19 Mei 2018)

FAO. (2015). The economic lives of smallholder farmers. In Food and Agriculture Organization of the United Nations. United Nations. https://doi.org/10.5296/rae.v6i4.632 0

Goverment of Indonesia. (2009). UndangUndang Nomor 41 Tahun 2009 tentang Perlindungan Lahan Pertanian Pangan Berkelanjutan. Goverment of Indonesia.

Indonesia Centre of Statistics Bureau. (2014). Potensi Pertanian Indonesia (Analisis Hasil Pencacahan Lengkap Sensus Pertanian 2013). Indonesia Bureau of Statistics (BPS).

Indonesia Centre of Statistics Bureau. (2020). Indonesia in Figure. Indonesia Bureau of Statistics (BPS).

Kosanlawit, S., Soni, P., \& Shivakoti, G. P. (2017). The relationship between effective and equitable water allocation, local rice farmer participation and economic wellbeing: Insights from Thailand's Chiang Mai Province. Water (Switzerland), 9(5). https://doi.org/10.3390/w9050319 
Kumar, A., Mishra, A. K., Sonkar, V. K., \& Saroj, S. (2020). Access to credit and economic well-being of rural households: Evidence from Eastern India. Journal of Agricultural and Resource Economics, 45(1), 145160.

https://doi.org/10.22004/ag.econ.29 8439

Latruffe, L., \& Piet, L. (2014). Does land fragmentation affect farm performance? A case study from Brittany, France. Agricultural Systems, 129, 68-80. https://doi.org/10.1016/j.agsy.2014. 05.005

Lu, W., \& Horlu, G. S. A. (2017). Economic well-being of rural farm households in Ghana: A perspective of inequality and polarisation. Journal of Rural Studies, 55, 248262.

https://doi.org/10.1016/j.jrurstud.20 17.08.013

Ma, W., Nie, P., Zhang, P., \& Renwick, A. (2020). Impact of Internet use on economic well-being of rural households: Evidence from China. Review of Development Economics, 24(2), 503-523. https://doi.org/10.1111/rode.12645

Markussen, T., Fibæk, M., Tarp, F., \& Tuan, N. D. A. (2018). The Happy Farmer: Self-Employment and Subjective Well-Being in Rural Vietnam. Journal of Happiness Studies, 19(6), 1613-1636. https://doi.org/10.1007/s10902-0179858-x

Menteri Tenaga Kerja dan Transmigrasi Indonesia. (2012). Peraturan Menteri Tenaga Kerja dan Transmigrasi Republik Indonesia Nomor 13 Tahun 2012 tentang Komponen dan Pelaksanaan Tahapan Pencapaian Kebutuhan Hidup Layak.
Milton, C. C. (2003). Innovating Conservation Agriculture: The Case of No-Till Cropping. Rural Sociology, 68(2), 278-304.

Nipers, A., Pilvere, I., \& Krievina, A. (2015). Sizes of Farmland Necessary for Earning Minimum Income and Investment Required for Farms of Various Specialisation in Latvia. Engineering for Rural Development Engineering For Rural Development Jelgava, 20-22.05.

NTB Province Statistics Bureau. (2017). Hasil Survei Struktur ongkos Usaha Tanaman Padi 2017/Result of Cost Structure Paddy Cultivation Household Survey 2017.

NTB Province Statistics Bureau. (2020a). NTB Province in Figure. NTB Bureau of Statistics (BPS).

NTB Province Statistics Bureau. (2020b). Statistik Harga Produsen Gabah Provinsi Nusa Tenggara Barat 2019.

Parnell, S., \& Oldfield, S. (2014). The Routledge Handbook on Cities of the Global South. Routledge. https://doi.org/10.4324/9780203387 832

Pochanasomboon, A., Attavanich, W., \& Kidsom, A. (2020). Impacts of Land Ownership on the Economic Performance and Viability of Rice Farming. Land, 9(71), 1-18.

Rusdiana, S. (2014). Analisis Pendapatan Usaha Pertanian Dan Peternakan Kerbau Di Lombok, Nusa Tenggara Barat. Journal of Agriculture, Resource and Environmental Economics, 1(2), 56-67. https://doi.org/10.29244/jaree.v1i2. 11802

Saxby, H., Gkartzios, M., \& Scott, K. (2018). 'Farming on the Edge': Wellbeing and Participation in AgriEnvironmental Schemes. Sociologia 
Ruralis, 58(2), 392-411. https://doi.org/10.1111/soru.12180

Setiawan, I. (2000). Dinamika Pemberdayaan Petani: Sebuah Refleksi dan Generalisasi Kasus di Jawa Barat. Bandung: Widya Padjadjaran.

Sumarno. (2006). Periodisasi Musim Tanam Padi Sebagai Landasan Manajemen Produksi Beras Nasional. Sinar Tani, 3136.

Sunderlin, W. D., Angelsen, A., Resosudarmo, D. P., Dermawan, A., \& Rianto, E. (2001). Economic crisis, small farmer well-being, and forest cover change in Indonesia. World Development, 29(5), 767782. https://doi.org/10.1016/S0305750X(01)00009-2

Susilowati, S. H., \& Maulana, M. (2012). Farm Business Land Size and Farmers Welfare: Smallholders
Existence and Agrarian Reform Urgency. Analisis Kebijakan Pertanian, 10(1), 17-30.

Swinnen, J., \& Knops, L. (2013). Land, Labour and Capital Market in European Agriculture. Brussel: Centre for European Policy Studies.

The Business Line. (2018, August). Average farm landholding size shrinks to 1.1 ha. Agri Business. https://www.thehindubusinessline.c om/economy/agri-business/averagefarm-landholding-size-shrinks-to11-ha/article24719240.ece.

Väth, S. J., Gobien, S., \& Kirk, M. (2019). Socio-economic well-being, contract farming and property rights: Evidence from Ghana. Land Use Policy, 81(April 2017), 878-888. https://doi.org/10.1016/j.landusepol. 2017.04.023 